\title{
Development of vegetable farming: a cause of the emergence of insecticide resistance in populations of Anopheles gambiae in urban areas of Benin
}

\author{
Anges William M Yadouleton*1,2, Alex Asidi'1, Rousseau F Djouaka3, \\ James Braïma $^{3}$, Christian D Agossou ${ }^{1}$ and Martin C Akogbeto ${ }^{1}$
}

Address: ${ }^{1}$ Centre de Recherche Entomologique de Cotonou, 06 BP 2604, Benin, ${ }^{2}$ University of Abomey-calavi, Benin and ${ }^{3}$ International Institute of Tropical Agriculture, 08 BP 0932 Cotonou, Benin

Email: Anges William M Yadouleton* - anges33@yahoo.fr; Alex Asidi - Alex.Asidi@lshtm.ac.uk; Rousseau F Djouaka - r.djouaka@cgiar.org; James Braïma - b.james@cgiar.org; Christian D Agossou - ddkunda@yahoo.fr; Martin C Akogbeto - akogbetom@yahoo.fr

* Corresponding author

Published: 14 May 2009

Malaria Journal 2009, 8:103 doi:10.1186/1475-2875-8-103

This article is available from: http://www.malariajournal.com/content/8/1/103

(C) 2009 Yadouleton et al; licensee BioMed Central Ltd.

This is an Open Access article distributed under the terms of the Creative Commons Attribution License (http://creativecommons.org/licenses/by/2.0), which permits unrestricted use, distribution, and reproduction in any medium, provided the original work is properly cited.

\begin{abstract}
Background: A fast development of urban agriculture has recently taken place in many areas in the Republic of Benin. This study aims to assess the rapid expansion of urban agriculture especially, its contribution to the emergence of insecticide resistance in populations of Anopheles gambiae.
\end{abstract}

Methods: The protocol was based on the collection of sociological data by interviewing vegetable farmers regarding various agricultural practices and the types of pesticides used. Bioassay tests were performed to assess the susceptibility of malaria vectors to various agricultural insecticides and biochemical analysis were done to characterize molecular status of population of An. gambiae.

Results: This research showed that:

(I) The rapid development of urban agriculture is related to unemployment observed in cities, rural exodus and the search for a balanced diet by urban populations;

(2) Urban agriculture increases the farmers' household income and their living standard;

(3) At a molecular level, PCR revealed the presence of three sub-species of An. gambiae (An. gambiae s.s., Anopheles melas and Anopheles arabiensis) and two molecular forms (M and S). The kdr west mutation recorded in samples from the three sites and more specifically on the $M$ forms seems to be one of the major resistance mechanisms found in An. gambiae from agricultural areas. Insecticide susceptibility tests conducted during this research revealed a clear pattern of resistance to permethrin (76\% mortality rate at Parakou; $23.5 \%$ at Porto-Novo and $17 \%$ at Cotonou).

Conclusion: This study confirmed an increase activity of the vegetable farming in urban areas of Benin. This has led to the use of insecticide in an improper manner to control vegetable pests, thus exerting a huge selection pressure on mosquito larval population, which resulted to the emergence of insecticide resistance in malaria vectors. 


\section{Background}

Malaria is one the deadliest vector-borne disease in the world with 1.5 to 3 million deaths a year [1]. More than $90 \%$ of the deaths recorded occur in Africa affecting mainly low immune response individuals, such as children under five years of age and pregnant women $[2,3]$. In 1992, the WHO set up sustainable strategies against malaria, focused on the proper treatment of malaria cases and the use of preventive measures against malaria vectors. Indoor residual spraying (IRS) and long-lasting insecticidal nets (LLINs) remain the two preventive measures presently used against malaria vectors. Both methods have been very effective in controlling Anopheles mosquitoes [4-10]. However the emergence of Anopheles gambiae populations carrying the $k d r$ gene has become a serious threat to the future effectiveness of these control measures [3]. N'Guessan et al [11] recently established a clear relationship between pyrethroid resistance caused by $k d r$ and the failure of LLINs and IRS in experimental huts in south Benin.

In the last decade, the emergence of resistance in populations of Anopheles to common class of insecticides used in public health was reported from many African countries $[7,8]$. Resistance affects the major vectors of malaria, An. gambiae s.l [4] and Anopheles funestus s.l [5]. The resistance of pyrethroid insecticides in An. gambiae has been documented in several parts of Africa $[8,9,12,13]$ and has prompted considerable research activity to investigate mechanisms of resistance and factors contributing to the emergence of insecticide resistance $[11,14]$. There is currently a growing agricultural activity within and around African cities. In Benin, the urban farming has spread in almost all the major cities all over the country. Akogbeto et al $[14,15]$ reported that mosquito species, An. gambiae in particular, lay their eggs in breeding sites located around agricultural settings. These eggs undergo a selection pressure from agricultural pesticides, which leads to the emergence of resistant strains. There is clear evidence on the implication of agricultural breeding sites in the selection of resistance in the major malaria vectors.

Indeed, a fast development of urban agriculture has recently been recorded in most settings in the Republic of Benin. At all levels of the society, people are devoted themselves to it. The reason which underpins the phenomenon is the impoverishment of the soil far from the town due to its overuse, rural exodus, unemployment, improvement of living standards, and the dietary requirement of urban population to be met.

Being ideal environments for larval growth, it has been reported that vegetable farming uses a large variety of synthetic pesticides for pest control [16]. Some of these insecticides are registered for pest treatments in vegetable farms, whereas many are not [14-16]. During treatment, insecticide residues are washed away into the mosquito breeding sites thus exerting a selection pressure on larvae population $[14,15]$. This selection leads to the emergence of insecticide resistance in the population of An. gambiae breeding in these sites. The massive utilization of agricultural pesticides constitutes, therefore, a public health issue in tropical Africa [14,15].

This study was designed to assess the impact of the fast growing activities of vegetable farming on the resistance status of malaria vectors in three localities (Cotonou, Porto-Novo and Parakou) in Benin. The study focused on the investigation of agricultural practices in vegetable farming in urban areas, and their impact on the emergence of insecticide resistance in populations of An. gambiae.

\section{Methods \\ Study sites}

The study was conducted in the Republic of Benin, from July 2005 to February 2007 in three vegetable farms: Houeyiho in Cotonou, the economical capital of Benin, Acron in Porto-Novo, the political capital of Benin, and Azèrèkè near Parakou, in the northern part of the country.

\section{The vegetable farm of Houeyiho, Cotonou}

This farm is located at $6^{\circ} 45^{\prime} \mathrm{N}$ and $2^{\circ} 31^{\prime} \mathrm{E}$ in the downtown of Cotonou in a highly populated quarter. It is a 14hectare farm shared between five cooperatives, each led by a chosen cooperative president. Each cooperative approximately consists of 300 individuals making an estimated farmer population of not less than 2,000 persons.

\section{The vegetable farm of Acron, Porto-Novo}

Located in south-eastern Benin at $6^{\circ} 30^{\prime} \mathrm{N}$ and $2^{\circ} 47^{\prime} \mathrm{E}$ at the outskirt of Porto-Novo, the vegetable farm of Acron is the oldest one in Benin. This site was established by missionaries in 1945. The farm consists of three hectares, nitially cultivated by 10 farmers. The activities of the farm have now grown and the size has widened from three to 20 hectares. The number of farmers has also increased to about 150 individuals.

\section{The vegetable farm of Azèrèkè, Parakou}

This farm is located at $9^{\circ} 22^{\prime} \mathrm{N}$ and $2^{\circ} 40^{\prime} \mathrm{E}$ at the entrance of Parakou town, known as Azèrèkè site. The size of this vegetable plantation is 10 hectares. The farm is crossed by a canalization of rainfall from the main town. The vegetable farm of Azèrèkè is mostly cultivated by men of 35 to 50 years old and their children. 


\section{Collection of data on the rapid spread of vegetable farms in Benin}

To generate adequate information on the fast spread of vegetable farms in Benin, knowledge-attitude-practice (KAP) studies were organized in the study sites of Houeyiho, Acron and Azèrèkè. A total number of 150 farmers were interviewed at Houeyiho, 80 at Acron and 60 at Azèrèkè. Farmers were subjected to semi-structured questionnaires focused on the history of vegetable farms, the size of farms, the number of workers, their educational levels, the type of vegetable grown, the farming techniques, the pesticides utilization in the farm. Qualitative data were recorded from direct observations, in-depth interview and focus group discussion.

\section{Insecticide susceptibility test}

To assess the impact of agricultural pesticides on the selection of resistance in malaria vectors, Anopheles larvae were collected from vegetable farms and reared to adults in the insectaria. Females mosquitoes aged 2-5 days old were subjected to susceptibility tests using insecticide-impregnated papers, as described by the WHO testing protocol [17]. Deltamethrin papers, impregnated at the diagnostic concentration of $0.05 \%$, were used in this susceptibility assay. Results with this insecticide were compared with permethrin-impregnated paper $(0.75 \%)$ and DDT-treated paper $(4 \%)$. DDT and permethrin were both tested to detect the presence of cross-resistance between pyrethroids and organo-chlorine in Anopheles populations. Female Anopheles used in this bio-assay were exposed for one hour to insecticide-treated papers and were monitored at different time intervals $\left(10^{\prime}, 15^{\prime}, 20^{\prime}, 30 ', 45^{\prime}, 60^{\prime}\right)$ to record "knock-down" times.

After 24-hour holding, delayed mortality was recorded. Following the WHO protocol, populations of Anopheles giving mortality rates below 95\% after exposure to insecticide-impregnated papers were considered resistant. In this study, these criteria were slightly modified as follow:

- Mortality rates between 100-95\%: the population was considered fully susceptible

- Mortality rates between 94-90\%: the population was considered less susceptible

- Mortality rates below 90\%: the population was considered resistant to the tested insecticides.

Based on the criteria mentioned above, data from insecticide susceptibility tests were used to characterize the susceptibility levels of An. gambiae populations in the three study sites. Dead and survived mosquitoes from this bioassay were separately kept in Carnoy solution at $-20^{\circ} \mathrm{C}$ for further molecular characterization.

\section{Data analysis}

Sociological information from focus group discussions, in-depth interviews and questionnaires conducted in studied communities were compiled and tabulated using Excel software and qualitative data were analysed by Text Base-Beta Software. Insecticide susceptibility test on the resistant strains from Houeyiho, Acron and Azèrèkè were compared and analysed using Stat-calc-Epi-info Software to get the status of resistance in the different sites investigated. A Fisher's exact test was performed to determine the differences between the three sites.

\section{Results}

Management of vegetable farms in Benin

At economical level, urban agriculture offers several advantages to farmers: quantitative and qualitative data from interviews and focus group discussion conducted in the three study sites revealed a major socio-economical impact of urban vegetable farming in households. Statistical studies conducted in vegetable farms of Benin for this research have shown that this activity produces each year more than 300 million FCFA to farmers [16,18]. This study has also shown that vegetable farming contributes to the development of husbandry by buying several end products and natural fertilizers like animal excreta. Vegetable farms consume each year more than 50 tones of natural fertilizers per hectare surface from husbandry, which represents one million franc CFA per hectare purchased to as fertilizers by aviculturist.

During investigation in the field, many pesticides were used but farmers declared that most of the insecticides were not registered for pest control in vegetable farms (Figure 1).

At social level, urban agriculture absorbs unemployed people by providing several job opportunities. In Cotonou, vegetable farms employ directly and permanently a total number of 3,600 workers, of which 600 are heads of groups and 3,000 are work members [16,18,19]. Subsequently, indirect beneficiaries, such as vegetable and pesticide sellers, also generate substantial incomes from vegetable farming. Series of training on agricultural practices are organized in these farms and are directed to unemployed youth.

\section{Susceptibility of vectors to agricultural insecticides}

5,000 three-day old female An. gambiae were exposed to three insecticide-impregnated papers (permethrin at $0.75 \%$; deltamethrin at $0.05 \%$ and DDT at $4 \%$ ). Mortality in control tubes was less than $5 \%$.

\section{Susceptibility of An. gambiae to pyrethroids}

4,000 three- to five-day old female An. gambiae mosquitoes from Cotonou and Porto-Novo were exposed to per- 


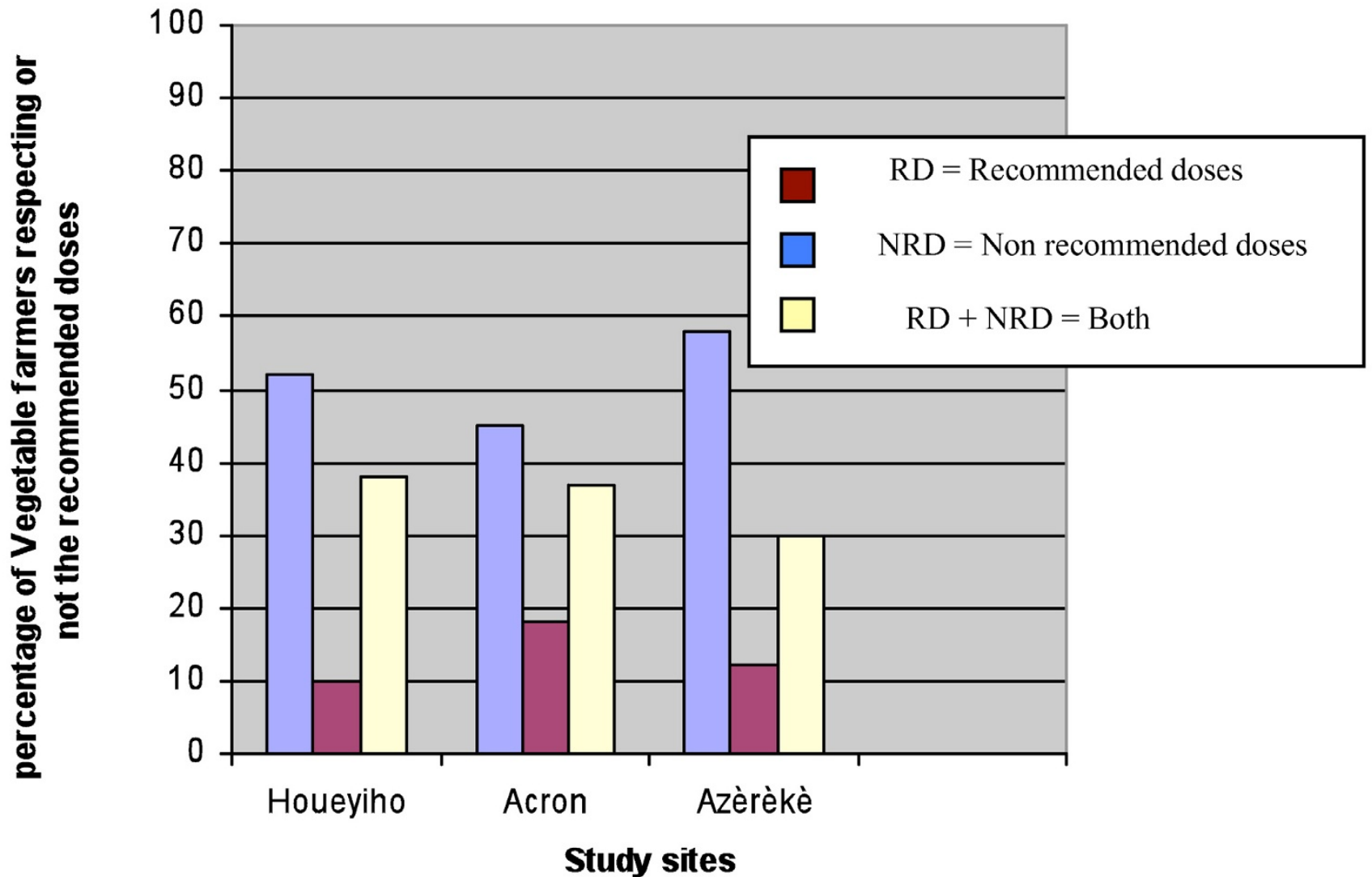

Figure I

Doses used by vegetable farmers at the three study sites.

methrin. Mosquitoes tested with pyrethroid insecticides showed very low levels of mortalities (Table 1 ), which varied between $17 \%$ and $35.5 \%$ in Cotonou and $23.5 \%$ in the Porto-Novo site, respectively. The highest mortality rate $(80.5 \%)$ was recorded during the rainy season with females from the vegetable farm of Houeyiho. A gradual lost of susceptibility to deltamethrin was observed with mortalities ranging from $86 \%$ to $90 \%$ in Cotonou and $91 \%$ in Porto-Novo.

A total number of 1,500 female An. gambiae, collected in vegetable farm of Parakou, was exposed to permethrinimpregnated papers. Mortality ranged from $76 \%$ to $80 \%$. These mortality rates revealed the emergence of permethrin resistance in An. gambiae in this study site (Table 1). Concerning deltamethrin $0.05 \%$, the mortality recorded ranged from 90.5 to $93.5 \%$, suggesting the emergence of deltamethrin resistance in these populations.

\section{Cross-resistance to DDT and pyrethroids}

Only specimens of An. gambiae collected at Cotonou and Porto-Novo sites were tested with DDT. In both localities,
Anopheles were found resistant to permethrin and deltamethrin (Table 2). Low mortality rates were recorded with DDT $(13.75 \%$ to $15.41 \%)$ (Table 3$)$. This resistance observed with the DDT indicates a cross-resistance to the DDT and pyrethroids.

\section{Determination of molecular forms and identification of species characterizing vegetable farms}

Table five shows that $95 \%$ of mosquitoes analysed by PCR in Cotonou were An. gambiae s.s and 5\% were An. melas. In Porto-Novo, 92\% were An. gambiae and 8\% An. melas. In Parakou, 85\% were An. gambiae ss and 15\% An. arabiensis. The characterization of molecular forms of An. gambiae from the northern site of Parakou gave 35\% of « $M$ » forms and $65 \%$ of « $S$ » forms. By contrast, in the southern Benin at Houeyiho and Acron sites only « $M$ » forms was found (Table 4).

\section{Frequency of kdr mutations (Leu-phe) on resistant populations of Anopheles from vegetable farms}

The PCR analysis of mosquito samples from Houeyiho (Cotonou) and Akron (Porto-novo) revealed high fre- 
Table I: Pesticides commonly used in vegetable farms at the three study sites

\begin{tabular}{|c|c|c|}
\hline Commercial name & Active ingredient & Family \\
\hline Cyhalone & deltamethrin & pyrethroid \\
\hline Decis & deltamethrin & pyrethroid \\
\hline Kinikini & mixture of cyfluthrin+malathion & pyrethroid \\
\hline Rugby (Orthene) & cadufos $10 \mathrm{~g}$ & pyrethroid \\
\hline Cytoate 335EC (Cypercal D335) & $\begin{array}{l}\text { mixture of cypermethrin } 35 \mathrm{~g}+ \\
\text { dimethoate } 300 \mathrm{~g} / \mathrm{l}\end{array}$ & Pyrethroid \\
\hline Furadan & carbofuran & carbamate \\
\hline Malathion & malathion $500 \mathrm{~g} / \mathrm{l}$ & organochlorine \\
\hline Topsin-M & methylthiophanate $70 \%$ & organophosphorus \\
\hline Nurelle D35/300 & mixture of cypermethrin $35 \mathrm{~g} / \mathrm{l}+$ chlorpyriphos methyl $300 \mathrm{~g} / \mathrm{l}$ & organophosphorus \\
\hline Dursban BI8/300 & $\begin{array}{l}\text { mixture of cyfluthrin } 18 \mathrm{~g} / \mathrm{l}+ \\
\text { chlopyriphos ethyl } 300 \mathrm{~g} / \mathrm{l}\end{array}$ & organophosphorus \\
\hline Callisulfan 350EC & endosulfan $350 \mathrm{~g} / \mathrm{l}$ & cyclodiene \\
\hline
\end{tabular}

Source: Benin Minsitry of Agriculture; 2007

quencies of $k d r$ mutation in An. gambiae populations: $88 \%$ in Houeyiho and $86.7 \%$ in Acron. This mutation was also found at $82.2 \%$ in samples of An. gambiae from Parakou (Table 5). However, analysis of An. arabiensis and An. melas collected during this study showed no $k d r$ mutation. The $k d r$ mutation is likely to be the main mechanism of resistance in An. gambiae in Benin.

\section{Discussion and conclusion}

Information collected during the interviews with farmers and the direct observations made confirmed a fast growing activity of vegetable farming and their economical impact in Benin. Urban agriculture contributes to food security and balanced diets. It provides additional incomes to populations throughout the year.
A field study conducted in Benin revealed that vegetable farming yields about 300 million FCFA annually to farmers in Benin with 30 to $40 \%$ used for direct consumption in farmers daily diet $[3,15,20]$. There is a clear evidence that vegetable farming activities do absorb unemployment and eventually reduce hunger [16,19-21].

Based on its numerous advantages, vegetable farming is becoming a new activity involving the various social groups: men, women, and children, educated, non-educated and even civil servants. More than 3,000 individuals are employed by urban farming and this sector is mainly man-powered by young people between 20 and 40 years of age. The massive use of pesticides in vegetable farms was confirmed during interviews with farmers. Some of

Table 2: Susceptibility of Anopheles gambiae s.s.* to permethrin and deltamethrin at the three study sites

\begin{tabular}{|c|c|c|c|c|}
\hline & \multicolumn{2}{|c|}{ Permethrin $(0.75 \%)$} & \multicolumn{2}{|c|}{ Deltamethrin $(0.05 \%)$} \\
\hline & Number tested & $\%$ Mortality & Number tested & $\%$ Mortality \\
\hline Houyiho & 1500 & $18.5^{\mathrm{a}}$ & 1500 & $97.5^{\mathrm{a}}$ \\
\hline Acron & 1500 & $22,5^{a}$ & 1500 & $98^{a}$ \\
\hline Azérèkè & 1500 & $76.5^{b}$ & 1500 & $98.5^{\mathrm{a}}$ \\
\hline
\end{tabular}

NB. Numbers in the same column with the same superscript do not differ significantly by Fisher test $(\mathrm{P}>0.05)$

*Tested Anopheles were collected from the vegetable farms of Houeyiho, Acron and Azérèkè. 
Table 3: Susceptibility of Anopheles gambiae s.s. to DDT at two study sites

\begin{tabular}{lllll}
\hline & & & DDT \\
\cline { 2 - 5 } & Number tested & Death after 24 h & Alive after 24 h & Mortality (\%) \\
\hline Houyiho & 1200 & $165^{\mathrm{a}}$ & $1045^{\mathrm{a}}$ & $13.75^{\mathrm{a}}$ \\
Acron & 1200 & $185^{\mathrm{a}}$ & $1015^{\mathrm{a}}$ & $15.41^{\mathrm{a}}$ \\
\hline
\end{tabular}

the pesticides recorded in vegetable farms were not registered, probably because of the liberalization of the pesticide sector and the elevated cost of registered pesticides (Table 1). Uncontrolled use of pesticides in Benin has resulted in the emergence of insecticide resistance in $A n$. gambiae larvae breeding in vegetable farms. The emergence of pyrethroid resistance in An. gambiae has become a serious concern to the success of malaria control in the last decade $[22,23]$. This study showed that pyrethroid insecticides used in vegetable farms are similar to those used in public health against malaria vectors. Pyrethroids remain the only family of insecticides currently registered for the impregnation of bed-nets, the major control strategy against malaria vectors $[6,24]$. Among the pyrethroids, deltamethrin is definitely the most used in both public health and agriculture. Cyfluthrin is one of the pyrethroids used in combination with organophosphates in agriculture $[14,15]$. The kinikini (in local language), which is a combination of cyfluthrin and malathion, is widely used in vegetable farming and in public health as Solfac $[14,15]$. Studies on insecticide resistance have been currently on most malaria agenda in Africa because of its impact on impregnated bed-nets the major tool against malaria vectors $[6,24]$. The first case of pyrethroids resistance in An. gambiae has been reported in Africa since the $1993[23,24]$. Dieldrin and DDT resistance were reported in Burkina-Faso with populations of An. gambiae [23,24]. Pyrethroids resistance was reported in An. gambiae in Côte d'Ivoire $[22,23]$ and later on many others cases of pyrethroid resistance in Anopheles vectors were detected in West [25], Central [24], Eastern [26] and Southern Africa [27].

In a recent study, a relatively high frequency of $k d r$ mutations (Leu-Phe) was recorded in An. gambiae collected from cotton farms under massive insecticide treatments compared to farms with no pesticide utilization $[22,23]$.
The $k d r$ mutation is probably responsible for the emergence of resistance of An. gambiae to DDT and pyrethroids in West Africa. The hypothesis of the implication of the $k d r$ mutation in the emergence of resistance has been confirmed in this research. In most localities where resistance was detected, the PCR analysis of samples revealed a high frequency of $K d r$ genes in localities of Cotonou and PortoNovo. This study provides further evidence on the contribution of the overuse of insecticide in agriculture to the widespread emergence of insecticide resistance in Anopheles species. In addition to the $k d r$ mutation, there are other existing factors, which seem to confer cross-resistance to pyrethroids and DDT, as described by Diabaté $e$ t al in the West African region [23].

The implication of metabolic mechanisms of resistance was not neglected in this study. Several studies are being currently conducted at CREC to determine the levels of acetylcholinesterase in An. gambiae after exposure to propoxur. In addition, elevated monooxygenase, esterases and glutathion-s-transferases have also been investigated. The increase number of vegetable farming in urban areas of Benin has been confirmed as a result of investigations made during this study from July 2005 to February 2007. This has led to the use of insecticide in improper manner to control vegetable pests, thus exerting a huge selection pressure on mosquito larval population leading to an emergence of mosquito resistance to insecticides.

More investigations need to be carried out in the future in order to better control the use of pesticides in vegetable farming within urban areas, especially in Benin where pyrethroid resistance has been widely reported in An. gambiae. These findings showed an increase emergence of resistance in An. gambiae populations in the vegetable farm breeding sites located not far from human dwellings. It is, therefore, important to set up insecticide manage-

Table 4: PCR determination of mosquito forms and species collected from the three study sites.

\begin{tabular}{|c|c|c|c|c|c|c|}
\hline & \multicolumn{3}{|c|}{ PCR (form) } & \multicolumn{3}{|c|}{ PCR (Species) } \\
\hline & Total tested & $\% \mathrm{~S}$ & $\% M$ & \% An. gambiae s.s. & $\%$ An. melas & $\%$ An. arabiensis \\
\hline Houyiho & 200 & & 200 & 198 & 2 & --- \\
\hline Acron & 200 & ---- & 200 & 192 & 8 & --- \\
\hline Azêrekê & 200 & 35 & 165 & 185 & ----- & 15 \\
\hline
\end{tabular}


Table 5: PCR characterization of kdr gene in An. gambiae collected from the three study sites

$$
\text { PCR } k d r
$$

\begin{tabular}{llllllll}
\hline & & \multicolumn{2}{c}{$\begin{array}{c}\text { Survivors } \\
\text { (Total tested per site: 200) }\end{array}$} & & & \multicolumn{2}{c}{$\begin{array}{c}\text { Dead } \\
\text { (Total tested per site: 100) }\end{array}$} \\
\hline RR & RS & SS & Kdr Frequency & RR & RS & SS & Kdr Frequency \\
\hline 60 & 120 & 20 & $90^{\mathrm{a}}$ & 7 & 20 & 73 & $27^{\mathrm{a}}$ \\
57 & 115 & 28 & $86^{\mathrm{a}}$ & 12 & 23 & 65 & $35^{\mathrm{a}}$ \\
45 & 98 & 57 & $71.5^{\mathrm{a}}$ & 5 & 15 & 80 & $20^{\mathrm{a}}$ \\
\hline
\end{tabular}

NB. Numbers in the same column with the same superscript do not differ significantly by Fisher's test $(P>0.05)$

ment structures to prevent failure from malaria vector control measures using especially those pyrethroid insecticides.

\section{Competing interests}

The authors declare that they have no competing interests.

\section{Authors' contributions}

AWY contributed to design of the study and conceived the protocol, the data analysis and interpretation. MCA contributed in the study design, fully involved financially and in the implementation of this research, guided the study from conception to the manuscript finalization and the write up of the manuscript. JB contributed in the study design and in the implementation of this research. AA, RFD and CDA contributed to the design of the study and substantially helped in drafting the manuscript.

\section{Acknowledgements}

We are grateful to the International Development Research Centre (IRDC) who through its AGROPOLIS grant programme. The author would like to thank the Malaria Research Training Center team, and IRD-Benin team, especially Dr Fabrice Chandre, for their help.

Many thanks to Vincent Ishola, Razack Ossé, Mouinath Souradjou and Gil Padonou for their technical assistance. The author is thankful to JeanClaude Dumais, Paul Viveiros, Mark Redwood and Alison Clegg for the administrative support.

\section{References}

I. Djouaka RF, Bakare AA, Bankole HS, Doannio JMC, Kossou H, Akogbeto MC: Quantification of the efficiency of treatment of Anopheles gambiae breeding sites with petroleum products by local communities in areas of insecticide resistance in the Republic of Benin. Malar J 2007, 6:56.

2. Danis M, Gentilini M: Le paludisme fléau mondial. Revue Praticien 1998, 48:254-257.

3. Gachot B, Bruneel F, Behr C: Paludisme pernicieux. Revue Praticien 200I, 5I:638-643.

4. Akogbéto M: Etude de la transmission du paludisme côtier lagunaire: Cas d'un village construit sur un lac d'eau saumâtre. Ann Soc Belge Méd Trop 1995, 75:2 19-227.

5. Beach R: International vector resistance testing. Annual Meeting of the American Mosquito Control Association, Larch, Utah 1997:23-27.

6. Carnevale P, Robert V, Boudin C, Halna JM, Pazart L-H, Gazin P, Richard A, Mouchet J: La lutte contre le paludisme par les mousti- quaires imprégnées de pyréthrinoïdes au Burkina-Faso. Bull 1988, 81 1:832-842.

7. Coluzzi M, Petrarca V: Aspirator with paper cup for collecting mosquitoes and others insects. Ann Soc Belge Méd Trop 1973, 33:249-250

8. Magesa SM, Wilkest J, Minzawa AEP, Myamba J, Philip MD: Trial of pyrethroid impregnated bed nets in area of Tanzania hole endemic of malaria. Part II. Effects on vector population. Acta Trop 1990, 49:97-108.

9. Service MV, Davidson G: A light incident of dieldrin resistance in An gambiae Giles from an unsprayed area in northern Nigeria. Nature 1964, 203:209-210.

10. Snow RW, Rowen KM, Lindsay SM, Greenwood BM: A trial permethrin treated bed nets prevention of malaria in Gambia children. Trans R Soc Trop Med Hyg 1988, 82:838-842.

II. N'Guessan R, Corbel V, Akogbeto M, Rowland M: Reduced efficacy of insecticide-treated nets and indoor residual spraying for malaria control in pyrethroid resistance area, Benin. Emerging infectious diseases 2007, I3(2): 199-206.

12. Hemingway J, Ranson $\mathrm{H}$ : Insecticide resistance in insect vectors of human disease. Ann Rev Entomol 2000, 45:37I-39I.

13. Burton GJ: Observations on the habits and control of Culex pipiens fatigans in Guyana. Bull World Health Organ 1967, 37:317-322

14. Akogbeto $M C$, Djouaka $R$, Noukpo H: Utilisation des insecticides agricoles au Bénin. Bull Soc Pathol Exot 2005, 98(5):400-405.

15. Akogbeto MC, Djouaka RF, Kinde-Gazard DA: Screening of pesticide residues in soil and water samples from agricultural settings. Malar J 2006, 5:22.

16. Assogba-Miguel V: Agriculture urbaine et périurbaine à Cotonou. Bulletin de la Recherche Agronomique du Bénin $n^{\circ} 27$ 1999:14-26.

17. WHO: Resistance of vectors and reservoirs of disease to pesticides: Tenth report of the WHO Expert Committee on Vector Biology and Control. WHO Technical Report Series, No. 737 Geneva. World Health Organization; 1986.

18. PADAP. Programme d'Appui au Développement Agricole Périurbain du Sud Bénin: Rapport de l'ètude Diagnostic: demande, offre et marchés et système de production. Tome 2, Agrisud International 2003: I48.

19. Hounkponou KS: Agriculture et Urbanisation: Analyse de la pression foncière sur les activités de maraîchage dans le Sud du Bénin. Cas de Cotonou, Ouidah et Grand-Popo. Thèse d'Ingénieur Agronome, FSA/UAC. I l Op 2003.

20. van Dijk PM: Le secteur informel dans les villes et sa contribution positive à leur développement. Le Courrier 1995:73.

21. Dongmo T, Gockowski J, Hernandez S, Awono L, Moudon M: L'agriculture périurbaine à Yaoundé: ses rapports avec la réduction de la pauvreté, le développement économique, la conservation de la biodiversité et de l'environnement. Tropicultura 2005, 23:130-135.

22. Diabaté A, Baldet T, Chandre F, Akogbeto M, Guiguemde T, Darriet F, Brengues C, Guillet P, Hemingway J, Small GJ, Hougard JM: The role of agricultural use of insecticides in resistance to pyrethroids in Anopheles gambiae s.I. in Burkina Faso. Am J Trop Med Hyg 2002, 67:617-622.

23. Diabaté A, Baldet T, Chandre F, Guiguemde T, Guillet P, Hemingway J, Hougard JM: First report of the kdr mutation in Anopheles 
gambiae M form from Burkina Faso, West Africa. Parassitologia 2002, 44: I57-I58.

24. Etang J, Manga L, Chandre F, Guillet P, Fondjo E, Mimpfoundi R, Toto JC, Fontenille D: Insecticide susceptibility status of Anopheles gambiae s.l. (Diptera: Culicidae) in the Republic of Cameroon. J Med Entomol 2003, 40:49I-497.

25. N'Guessan R, Darriet F, Guillet P, Carnevale P, Traore-Lamizana M, Corbel V, Koffi AA, Chandre F: Resistance to carbosulfan in field populations of Anopheles gambiae from Côte-d'Ivoire based on reduced sensitivity of acetylcholinesterase. Med Vet Entomol 2003, 17:19-25.

26. Vulule JM, Beach RF, Atieli FK, MCallister JC, Brogdon WG, Roberts JM, Mwangi RW, Hawley WA: Elevated oxidase and esterase levels associated with permethrin tolerance in Anopheles gambiae from Kenyan villages using permethrin impregnated nets. Med Vet Entomol 1999, 13:239-244.

27. Hargreaves K, Koerkemoer LL, Brooke B, Hunt RH, Mthembu J, Coetzee M: Anopheles funestus resistant to pyrethroid insecticides in South Africa. Med Vet Entomol 2000, 14:181-189.

Publish with Bio Med Central and every scientist can read your work free of charge

"BioMed Central will be the most significant development for disseminating the results of biomedical research in our lifetime. "

Sir Paul Nurse, Cancer Research UK

Your research papers will be:

- available free of charge to the entire biomedical community

- peer reviewed and published immediately upon acceptance

- cited in PubMed and archived on PubMed Central

- yours - you keep the copyright

Submit your manuscript here:

http://www.biomedcentral.com/info/publishing_adv.asp 